IRA-International Journal of Education \&

Multidisciplinary Studies

ISSN 2455-2526; Vol.17, Issue 02 (Q2, 2021)

Pg. no. 69-75.

IRA Academico Research

\title{
Ernest Hemingway's Female Consciousness
}

\section{Yuan Yongju}

School of Foreign Languages, Yangtze University, Hubei, 434023 PRC China.

Type of Work: Peer Reviewed.

DOI: 10.21013/jems.v17.n2.p4

DOI URL: https://dx.doi.org/10.21013/jems.v17.n2.p4

How to cite this paper:

Yongju, Y. (2021). Ernest Hemingway's Female Consciousness. IRA-International Journal of Education \& Multidisciplinary Studies (ISSN 2455-2526), 17(2), 69-75. DOI: https://dx.doi.org/10.21013/jems.v17.n2.p4

(C) IRA Academico Research.

(c) $\mathrm{EY}$-No International License subject to a proper citation to the publication source of the work.

Disclaimer: The scholarly papers as reviewed and published by IRA Academico Research are the views and opinions of their respective authors and are not the views or opinions of IRA Academico Research. IRA Academico Research disclaims any harm or loss caused due to the published content to any party.

IRA Academico Research is an institutional publisher member of Publishers International Linking Association Inc. (PILA-CrossRef), USA. IRA Academico Research is an institutional signatory to the Budapest Open Access Initiative, Hungary advocating the open access of scientific and scholarly knowledge. IRA Academico Research is a registered content provider under Open Access Initiative Protocol for Metadata Harvesting (OAl-PMH).

The journal is indexed \& included in WorldCat Discovery Service (USA), CrossRef Metadata Search (USA), WorldCat (USA), OCLC (USA), Open J-Gate (India), EZB (Germany) Scilit (Switzerland), Airiti (China), Bielefeld Academic Search Engine (BASE) of Bielefeld University, Germany, PKP Index of Simon Fraser University, Canada. 


\section{ABSTRACT}

Ernest is often stereotyped as a masculine writer as much of his work focuses on hunting, fishing, boxing, and bullfighting. With the rise of the women movement in the 1960s and feminist criticism in the department of literature, Hemingway became Enemy Number One for many critics, who accused him of perpetuating sexist stereotypes in his writing. By analyzing some female characters in his major works, this paper argues that as a skilful writer in depicting the male sphere, Hemingway has created many female characters that deserve commendation, and the mainstream of his female consciousness is positive. On the whole, his attitude toward women is fair.

Keywords: Hemingway; female characters; female consciousness

Critics have long been troubled by Hemingway's attitude toward women. With much of his work focusing on hunting, fishing, boxing and bullfighting, and most male characters being men of iron with "grace under pressure", he is often stereotyped as a masculine writer. From the very beginning of Hemingway's career, critics make an issue of "masculinity" in his writings. His early stories have won wide critical praise for their stoic, understated, "masculine" style and their graphic depiction of male pursuits and attitudes. Furthermore, fewer female characters are involved in his writings. In The Old Man and the Sea, he offers a world nearly devoid of real women. Consequently, many critics declare that Hemingway discriminates against, and even looks upon women with hatred. Especially with the rise of the women movement in the 1960s and feminist criticism in the department of literature, Hemingway becomes Enemy Number One for many critics, who accuse him of perpetuating sexist stereotypes in his writings. Edmund Wilson's observation in 1939 of a "split attitude and growing antagonism toward women" in Hemingway's work has provided a basic premise of Hemingway criticism for decades to come. He sees Hemingway's heroines as falling into two categories: the "submissive infra-Anglo-Saxon women that make his heroes such perfect mistresses" and "American bitches of the most soul-destroying sort", suspecting that Hemingway's instinct to get the woman down grows out of "a fear that the woman will get the man down" ( Edmond Wilson; 1939; p. 236-257).

Personally, these views go to an extreme. Hemingway indeed is concerned with the women sphere. He has elaborated on his feelings about women's virtues: "I have always believed that though both live under strict and rigid standards, it's much easier for the male to survive. Not a man will adhere to those stern standards as women, nor will a man have moral standards as good as women as he imagines, unless he does try hard." ( Hemingway; 1967 ;p. 461 ). In The Art of Short Story, He complains that it's very difficult to portray female characters, stating that you needn't worry when people doubt the existence of such women as you have created. It merely shows that your female characters differ from theirs Hemingway; 1989; p. 135). These may well display his concern about the female sphere.

However, this paper is not primarily to secure justice for Hemingway. It is hoped that by analyzing his female characters in his major works, his depiction of women and gender issues may be fruitfully approached.

\section{Hemingway's Sympathy and Respect for Women}

A common but mistaken assumption about Hemingway's fiction is that he automatically sides with his fictional males. Rena Sanderson holds "In fact, the stories in his first collection are consistently sympathetic to women, who are often revealed to be more mature than their mates."( Sanderson; 2000; p. 176) Although In their own world, Hemingway's men have an implied code of stoic manliness by which to define themselves, but 
in their relationship to women, that code does not assure success. In these stories the men seem very passive in response to women; they are either indifferent or insensitive, unwilling or unable to take action or to accept responsibility for the way things turn out. Several of Hemingway's finest and best-known stories such as Indian Camp and Hills Like White Elephant pivot on this very point. Some critics blamed the Indian woman, which goes against the intention of the author. His intention is very clear in the following dialogue between the doctor and his son: "Why did he kill himself, daddy?". "I don't know, Nick. He couldn't stand things, I guess." ( Hemingway, 1987; p. 69) It is clear that the cause of his death is internal, not external. The weakness in his character is the root cause of his suicide: not being strong enough to stand for sufferings, he has no choice but to escape. His internal weakness leads to the tragedy.

"Do many men kill themselves, Daddy?" "Not very many, Nick." "Do many women?" " Hardly ever. " "Don’t they ever" "Oh, yes, sometimes" (Hemingway; 1987; p. 69-70)

The indirect bearer of the suffering kills himself while the direct bearer stands up to it. In fact, when disaster comes, women stand up to it with great courage. They have suffered more, and what they have suffered make them tougher and more tensile.

Another viewpoint blames that the Indian woman is a destroyer of the man. As a matter of fact, the Indian woman is not a destroyer, but a giver of new life: she bears the suffering to bring a new life to the world. To Ernest Hemingway, who loves life deeply, it is a great and glorious cause. To Nick, what he receives is not only that the world is of nihility, and life is painful, but also that he should stand up to the nihility, and subjugate nihility and sufferings. In another short story Hills Like White Elephant, Hemingway portrays another man who attempts to escape his responsibility and another girl who shows her courage. Trying to persuade the girl to have an abortion, the man picks up the topic repeatedly: "It's really an awfully simple operation. " That's the only thing that bothers us. It's the only thing that's made us unhappy." "I don't worry about that because it's perfectly simple". "I don't want you to do anything that you don't want to do."( Hemingway; 1987;p.212-214)p. 212-214) The more he says, the more he betrays himself: selfish, hypocrite and irresponsible. Being sober-minded, the girl has seen through him and tries to hide her disappointment. In the early years of this century, abortion seemed to be very dangerous, especially to a girl who hasn't got married yet. A girl usually relies on the man when such an incident happens. Having no one to rely on, the girl in the story shows great courage towards it, and resolves on facing up to it alone: "The girl smiled brightly at the man." "She smiled at him." "She was sitting on the table and smiled at him." "There's nothing wrong with me. I feel fine" Overall, in Hemingway's eyes, the two male characters are regarded as cowards, far from his code-hero. Yet the female characters that are strong and mature are worth sympathy and respect. They most possibly originate from his actual life. During Hemingway's youth, his most serious relationship involved older, mature women. His first passion-the nurse Agnes von Kurowsky, his first wife Hadley, and his second wife Pauline-were all several years older than him.

\section{Hemingway's Appreciation of New woman}

The female role was undergoing a transformation after World War I in the popular consciousness from passive, private creature to avid individual in pursuit of new experiences. The household Victorian nurturer was becoming the modern woman of unprecedented mobility and public visibility. The culture of the 1920s was something new, embracing the first generation of women to smoke, drink and use divorce as a solution to a bad marriage. She was educated, valued her autonomy, and did not automatically subscribe to the values of the family. No longer did she define herself as a domestic being; openly rebelling against nineteenth-century 
bourgeois priorities, the new woman rejected the traditional feminine ideals of purity, piety, and submission. Instead, she insisted on reproductive freedom, self-expression, and a voice in public life. In short, the new woman rebelled against patriarchal marriage, and, protesting against a society that was rooted in female biology, she refused to play the role of the ethereal other. In addition, the war had given a generation of women an opportunity to test their abilities: service in the nursing or agriculture corps taught women not only that they would work efficiently but that their work was valuable. By the time American women gained the right to vote in 1920, a modern New Woman had appeared.

Quite clearly, the New woman contributes heavily to Hemingway's own image of the ideal woman (Sanderson; 2000; p.173). His intimate relationship with them obviously manifests his appreciation of New Woman which can be seen in Lady Brett Ashley, who has stepped off the pedestal and now roams the world.

A traditional woman is in fact a private creature of a man. As a New Woman, Brett Ashley will not submit to the authority or the direction of the man. She breaks up when her lovers attempted to claim her, that is to exercise authority over her. She even leaves the bullfighter Romero-a man to whom she is overwhelming attracted-when he shows signs of wanting to domestic her: he tells her to give up her mannish felt hat, to let her hair grow long, to wear more modest clothes. In traditional courtship situations, the woman's power is the power to be pursued; once caught, she forfeits her opportunity to choose. However, Brett keeps her options open, diversifies her investment of social and sexual energy, and thereby maximizes her opportunities.

Some critics ignore Hemingway's sympathetic treatment of Brett. In fact. the loose, disordered relationship on the other hand reflects what she has suffered. She has been a nurse on the Italian front. The war has turned her into the freewheeling equal of any man. It has taken her first sweetheart's life through dysentery and has sent her second husband home in a dangerous state of shock. These blows seem to expose her to the male prerogatives of drink and promiscuity. She has been wounded psychologically and emotionally by the war. In a word, she is also a victim of the war. Trying to relieve herself by indulging herself, she often vacillates between the extreme of self-abnegation and self-indulgence, and her relationships with Mike Campbell, Robert Cohn; and even Jake are filled with ambivalence, anxiety, and frequently alienation. What's more, she is not interested in exploiting her considerable erotic power for economic gain, refusing \$10,000 to spend a weekend with Mippipopolous. She will not take money for sex, because that would be prostitution.

\section{Hemingway's Admiration for Woman}

No character in all of Hemingway's fiction has provoked responses so numerous, so contradictory, and so strong as has Catherine Barkley in A Farewell to Arms. She has been idealized and reviled; her creator has been reviled for idealizing her. Some readers have objected to her passivity; others have found her malevolently active. Theodore Bardacke declares that her "complete subjection is the core of Hemingway's conception of the ideal woman" ( Bardacke; 1950; p. 346). They think that Hemingway's heroine is submissive and ignorant. In restoring the portrait of Catherine Barkley, it is crucial that we keep firmly in mind not only the aspects of $A$ Farewell to Arms but also its historical context. It must be remembered that world war I was a mechanized horror unprecedented in human history, a war of "stasis and futility" that exacted casualties hideous in their number. Having witnessed the cruelty of the war, Hemingway's world views changed. He experienced a bitter disillusionment and did not believe So-called 'glory' any longer. Instead, he realized that world war I was "the colossal, murderous, mismanaged butchery that has ever taken place on earth"(Hemingway; 1942; p. 5) Besides, in assessing Catherine's character, it is critical to remember that A Farewell to Arms takes place in a world in 
which the winner takes nothing, and those who play by the rules only lose more and faster than others. World War I was a war that had in effect deserted men, which had defaulted from every human value. Therefore, Catherine as one character in the novel, more than any other, embodies the control of courage and honor that many have called the "Hemingway code". Henry Hazlitt remarked that "the girl Catherine has a fine courage and a touch of nobility"( Hazlitt; 1929, p.38). Her intelligence and self-awareness are obvious and excellent in the novel.

Catherine has realized the war before the novel begins. Her faith in traditional values is blown to bits offstage, along with her boyfriend. She already knows what Frederic will learn: that people get blown up while eating cheese; that a good Italian soldier can get shot by Italians for no reasons other than starting across an open field; that in the violent and senseless world that this novel portrays, Humanity is like a swarm of ants on a long log at the mercy of an arbitrary and indifferent fate.

She has gone into nursing with the "silly idea" that her boyfriend might come to the hospital where she is: "With a sabre cut, I suppose, and bandage around his head. Or shot through the shoulder. Something picturesque." "They blew him all to bits." (Hemingway; 1932; p. 20) Later when Frederic wants to drop the war and get on with the seduction, Catherine remarks "there is no place to drop it" (Hemingway, 1932; P. 26). Catherine has come to the war fully wiser than the young man who happens into the war thinking it has a thing to do with him.

It is Catherine who challenges Frederic's statement that nothing ever happens to the brave. When they wonder who said that "the coward dies a thousand the brave but one", she corrects the statement: He was probably a coward. It is not so much that Catherine is more noble than Frederic, she is simply more experienced. Catherine has lost her true love to the war, but she seems strengthened. In retrospect, she realizes that she "didn't know about anything before the death of her true love" (Hemingway; 1932; p. 12). After that death, she behaves like someone who has been psychologically wounded by the war and by the loss of her first love, but she endures and gradually comes to realize the finality of death and what that implies for the living. Typical of Hemingway's heroic figures, Catherine not only accepts her pain but shares her insights and growth With Frederic( Sanderson; 2000; p. 181). What the priest and Catherine know (before Frederic himself discovers it) is that the only certainty in life is the imminence of death. In contrast to Frederic, the priest and Catherine realize that dissipation equals death and that the only choice is to snatch a fine life out of the jaws of death, to carve meaning out of meaninglessness, spirituality out of worldliness. In managing to snatch a fine life, Catherine has learned to disobey, to avoid obstacles more furiously than others. After learning she is pregnant, she thinks only "how small obstacles seemed that once were so big" and tells Frederic, "Life isn't hard to manage when you have nothing to lose." (Hemingway; 1932; p. 137). Her Self-reliance is also far more advanced than Frederic. She cares nothing for tradition or convention; her values are private and personal. When she checks into the hospital to have the baby, it is clear that her only allegiance is to herself and her love, indeed, her only religion. "She said she had no religion and drew a line in the space after that word. She gave her name as Catherine Henry". ( Hemingway; 1932;p.313)

In the context of the Great War, her willingness, even determination to submerge herself in a private love relationship can be seen as a courageous effort to construct a valid alternative existence in a hostile and chaotic universe. Again, Catherine's humor is a mark of strength and courage in the face of impossible circumstances. After a bad moment of feeling like a whore in the hotel on their last night together in Milan, Catherine transforms the hotel room to " home" by an exercise of sheer will. As she pulls herself together, her stiff-up-lip 
determination to put the best face on things is amusing and endearing. During their harrowing escape to Switzerland, she is able to laugh at how silly Frederic looks clutching the inside-out umbrella as he uses it as a sail. Even as she is dying in childbirth, she maintains a sense of humor: "I'm a fool about the gas. It's wonderful." Yet she is hardly a blind romantic retiring from the world at large for reasons of weakness or incompetence. It simply is not her show anymore. Indeed, Catherine' intelligence and resourcefulness and ability to cope in the social world place her in the category of confident and competent characters. We have noted that though A Farewell to Arms was finished long before Hemingway' last two marriages, virtues of Hemingway's wives-Hadley's faith, Pauline's maturity, Martha's courage and intelligence, Mary's adaptability and bravery, are concentrated on Catherine. In fact, she serves as the epitome of Hemingway wives. Rena Sanderson observes "Catherine emerges as a modern, independent young woman-quite possibly Hemingway's definition, at the time, of the ideal woman. Essentially, she is an improved-actually more modern-version Brett"( Sanderson; 2000; p. 180). She is sexually liberated, monogamous and faithful. Her ethical and moral standards are much more orthodox. Apart from those, she is self-reliant and competent, ready and qualified to run away with the man she loves and to help him domesticate the world of his wishful dreams.

\section{Conclusion}

Hemingway is well known to be an expert in depicting the Male sphere. Yet he has also displayed a keen sense of female consciousness, made unremitting efforts in portraying women sphere, and created many respect-worthy female characters. His attitude toward them is positive. For those who are strong and mature, he expresses the greatest esteem; to those New Woman, he shows his appreciation; and to those who are with great courage, intelligence and loyalty, he conveys his admiration. His female characters somewhat resemble his" code hero" with emphasis on courage and perseverance in the face of inevitable defeat and death.

Anyway, Hemingway has his limitation and inadequacy in the characterization of female characters, which may affect our understanding of his female consciousness. Some of his female characters are so physically and spiritually alike that they are almost identical. In addition, with more and more women playing an important role in almost every field, the role of women is changing rapidly. Women have a variety of choices of job. But Hemingway hasn't noticed that. Women in his books usually take up the traditional job, and some of them are unemployed, which will certainly lead to their lack of financial and psychological independence. These fully display his lack of understanding of women. Furthermore, an occasional ambivalence and perplexity in his attitude toward female characters are revealed.

However, taking a sweeping view of Hemingway's life, it's convinced that the mainstream of his female consciousness is positive. Basically, his attitude toward women is fair and just.

\section{References}

[1]. Baker Carlos, Ernest Hemingway: A Life Story. New York: Bantambooks, Bantam Edition, 1970

[2]. Bardacke Theodore, Hemingway's Women, " Ernest Hemingway: The Man and His Work. Ed. John K. M. McCaffery. New York: Avon, 1950.J

[3]. Fetterley Judith, The Resisting Reader: A Feminist Approach to American Fiction Bloomington: Indiana University Press, 1978

[4]. Hazlitt Henry, "Taking Hemingway". New York Sun, 28 September 1929

[5]. Hemingway Ernest, $A$ Farewell to Arms. New York: Scribner's, 1932

[6]. Hemingway Ernest, By-line: Selected Articles and Dispatches of Four Decades, Ed. William While. New York: 
Scribners, 1967.

[7]. Hemingway Ernest, " The Art of Short Story, " in Joseph M. Flora, Ernest Hemingway: A Study of the Short Fiction, Boston: Twayne Publisher, 1989

[8]. Hemingway Ernest, For Whom the Bell Tolls. London: Granada Publishing, 1941

[9]. Hemingway Ernest, The Sun Also Rises. New York: Scribner's, 1926

[10]. Sanderson Rena, Hemingway and Gender History in the Cambridge Companion to Hemingway. Ed. Scott Donaldson, Shanghai Foreign Language Education Press 2000

[11].Schneider, American Women in the Progressive Era, 1900-1920. New York Facts on File, 1993. 